\title{
INFORMATION ABOUT THE AUTHORS
}

Olena Yemelyanova - Associate Professor, Ph.D. in Philological Sciences, Candidate of Philological Sciences, Associate Professor of the Department of Germanic Philology, SSU.

Scientific interests: discourse studies, text-discourse categories, linguistics of the text

Mariia Titareva - 2d year master student of the Faculty of Foreign Philology and Social Communications of Sumy State University.

Scientific interests: discourse studies, text-discourse categories, linguistics of the text

Tetiana Popova - 2d year master student of the Faculty of Foreign Philology and Social Communications of Sumy State University.

Scientific interests: discourse studies, text-discourse categories, linguistics of the text

\author{
УДК 811.111’373:355.01 \\ DOI: 10.36550/2522-4077-2021-1-193-133-139
}

\section{РЕПРЕЗЕНТАЦІЯ КОНЦЕПТУ WAR В АНГЛОМОВНІЙ ЛІНГВОКУЛЬТУРІ}

\author{
Олена ШЕВЧЕНКО (Полтава, Украӥна) \\ ORCID: 0000-0002-5829-2048 \\ e-mail: Shevchenko.36028@gmail.com
}

\begin{abstract}
ШЕВЧЕНКО ОЛЕНО. РЕПРЕЗЕНТАЦЯ КОНЦЕПТУ WАR В АНГЛОМОВНІЙ ЛІНГВОКУЛЬТУРІ. У статті на матеріалі англійського художнього дискурсу виявлено особливості вербалізачії та структурування концепту WAR. 3'ясовано основні лексичні вербалізатори концепту WAR в англомовній лінгвокультурі. Концепт формує як сегмент, щзо має негативне маркування та передбачає компоненти смерть, розруха, зрада, підлість, ненависть тощо, так і позитивно оцінений сегмент із складниками свобода, життя, любов, гідність, героїзм.

Ключові слова: лінгвокультурологія, дискурс, конщепт, світогляд, конщепџія війни, мовна свідомість, етимологія, актуальність концепту, концептуальний компонент.

SHEVCHENKO OLEA. REPRESENTATION OF THE CONCEPT OF WAR IN ENGLISH LANGUAGE CULTURE. The features of verbalization and structuring of the concept war on the material of the artistic discourse in English language culture are revealed in the article. It is found out how the conceptualization has led to its development. At the beginning of the 20th century, international relations have dramatically changed in the world. There is a risk that people of different worldviews may interpret certain military notions (in particular the linguocultural concept WAR) otherwise. The solution of this complex problem of ambiguity must be sought in the etymology of the linguocultural concept WAR and its lexical field. The concept of WAR is vividly expressed in the English-language picture of the world, and its expression has a deep national and cultural specificity. Subject-image, conceptual and value components can be distinguished in the structure of this concept. The semantic field of the WAR concept consists of the kernel (the "State of Armed Conflict" microfield) and the semantic periphery objectified by the "Situation of Antagonism" and "Art of War" microfields. The main lexical verbalizers of the WAR concept were also identified. These include the war token itself, as well as the corresponding synonymous tokens and lexical associations. A new understanding of the concept of WAR is observed within the English-language artistic and journalistic discourses, which is realized in the system of conceptual metaphors. The concept war in the artistic discourse of participants is a multidimensional mental formation, very complex, encompassing radically opposite meanings. It is clear that the sense of the concept includes components that are associated with death, agitation, pain, horror, depression and more. At the same time the structure of the concept includes extremely positive meanings that can be verbalized in such words as life, love, honesty, help, heroism. For each war, it carries something personal, but always war is when the heart aches.

Key words: cultural linguistics, discourse, concept, worldview, the concept of war, language consciousness, etymology, relevance of the concept; conceptual structure; conceptual component.
\end{abstract}

Актуальність дослідження визначається значимістю концепту WAR в концептуальній картині світу. Традиційно військова справа відігравала важливу роль в англомовному соціумі. У світлі подій останніх років можна зробити висновок, що актуальність та важливість дослідження даного концепту не підлягають сумніву. Концепт WAR вивчався у лінгвістиці, наприклад, на основі публіцистичного та політичного дискурсів (Lakoff, 1991, 
2006; Венедиктова, 2004), рідше на матеріалі літературного дискурсу. Тим часом, феномен війни завжди породжував творчість: війна, боротьба, двобій - ключові теми як найдавніших епічних оповідей, так і художніх творів останніх двох століть.

Аналіз останніх досліджень і публікацій. Концепт є об'єктом уваги фахівців різних наукових галузей (Брославська, 2016; Верьовкін, 2013), що робить його міждисциплінарним феноменом для сучасного наукового дискурсу.

Дослідники сходяться на думці, що концепти відбивають цілісну картину світу, яка існує поза мовним простором і лише вербалізується у ньому (Кубрякова, 1994). Концепт є одночасно поняттям індивідуальним та соціальним, що дозволяє науковцям досліджувати його у мовній картині світу певної спільноти (Карасик, 2010), або у мовній свідомості окремого індивіда (Кубрякова, 1994). Великого значення мають дослідження в руслі когнітивної та концептуальної лінгвістики і лінгвокультурології (Карасик, 2010; Кубрякова, 1994; Стернін, 2011; Шевченко, 2020).

Важливість і актуальність концепту ВІЙНА для багатьох націй у різні часи доводить той факт, що даний концепт досліджувався на матеріалі різних мов (української, англійської, французької) (Брославська, 2016; Верьовкін, 2012) і різних епох (Верьовкін, 2012; Вільчинська, 2017; Яворська, 2016). У межах сучасного наукового лінгвістичного простору щодо визначення концепту як основного семантичного поняття науковці досі не досягли одностайності. При цьому дослідники погоджуються у тому, що концепт має двоїсту (психічну та мовну) сутність. Нині чільну позицію займають когнітивний i лінгвокультурологічний підходи до опису універсальних концептів, до яких в тому числі належить концепт ВІЙНА.

Окремі аспекти мовного втілення концепту ВІЙНА в різних мовах уже виступали предметом досліджень, зокрема дисертаційних (Венедиктова, 2003; Верьовкін, 2017; Рабкіна, 2009).

Постановка проблеми. Серед концептів, які актуальні для усього людства, - концепт ВІЙНА. Його цінність умовна: це поняття займає певне місце у свідомості будь-якої людини. Для більшості - це вимушеність, пов'язана з втратою, розрухою, смертю. У мовному просторі сьогодення узвичаїлась лексема ВІЙНА. Британія та Сполучені Штати Америки за свою історію існування не одноразово піддавалися нападу іноземців, а також самі брали активну участь у війнах. Відтак, війна як суспільно-політичний феномен, знаходить яскраве втілення в англомовній картині світу. Англійські мовні одиниці, що репрезентують концепт $W A R$, не лише мають глибоку національно-культурну специфіку, а й пов'язані із сприйняттям дійсності та певним чином відображають пізнання світу, місце в ньому людини та іiі мовну картину. Як наслідок для лінгвістики - розвідки, що вивчають його вербалізацію, адже передусім за мовним виявом можна простежити його осмислення національною свідомістю.

Не вирішені раніше аспекти проблеми. Раніше ми вже розглядали лексичні репрезентації концепту WAR (Шевченко, 2020). Не менш цікавою і не вивченою до кінця $\epsilon$ структура даного концепту. Уваги заслуговую і таке питання як семантичне поле та лексичні вербалізатори концепту WAR.

Мета статті. Уточнити структуру концепту WAR та з'ясувати основні лексичні вербалізатори концепту $W A R$ в англомовній лінгвокультурі.

Виклад основного матеріалу. Концепт $W A R \in$ дуже важливим для людей, саме тому він являє собою детально сегментоване смислове утворення.

Дослідження структури концепту $W A R$, а також особливостей його вербалізації перебували у колі уваги багатьох лінгвістів. У рамках лінгвокогнітивного підхіду науковці у структурі концепту WAR виокремлюють наступні складники: предметно-образна сторона концепту (узагальнений образ протистояння ворогуючих сторін); понятійна сторона концепту (мовне позначення характеристик війни, поведінки учасників бойових дій); ціннісна сторона концепту (прийняті в суспільстві експліцитні та імпліцитні норми поведінки, що стосуються війни) (Венедиктова, 2004). 
У межах семантичного поля концепту WAR виокремлюють ядро та периферію. Ядро семантичного поля концепту WAR складає мікрополе «State of Armed Conflict» (Брославська, 2016: 27). Це мікрополе мотивоване семантичною ознакою «стан збройного конфлікту». До складу мікрополя «State of Armed Conflict» входять розширення «Period of Hostilities», «Particular Armed Conflict», «Legal State of War». До семантичної периферії концепту WAR належать два мікрополя: «Situation of Antagonism» та «Art of War» (Брославська, 2016: 27). Мікрополе «Situation of Antagonism» поєднано гіперсемою «ситуація протистояння», що вказує на стан неозброєної відкритої конфронтації. До складу мікрополя «Situation of Antagonism» входять розширення «Campaign», «Business Struggle» «Contest» i «Quarrel». Мікрополе «Art of War» поєднує лексеми-синоніми зі спільним значенням «методи/мистецтво ведення війни», що вказує на теоретичні знання про війну та їх реалізацію у професійній діяльності.

Концепт WAR в англомовній картині світу постає головним руйнівним началом всесвіту, втіленням негативних сил хаосу, що здатні поглинути існуючий лад. Оскільки концепт $W A R \in$ однією з основних категорій буття в англомовній лінгвокультурі, відповідний концепт вербалізується за допомогою значної кількості номінативних одиниць різного типу.

Концепт WAR найчастіше знаходить мовне втілення безпосередньо у лексемі $W A R-$ імені концепту, а також відповідних синонімічних лексемах та лексичних асоціаціях. За нашими даними аналізу лексикографічних джерел виокремлено 41 синоніми лексеми $W A R$ в англійській мові - імені концепту WAR: altercation, antagonism, argument, attack, battle, belligerency, blockade, bloodshed, campaign, clash, combat, competition, conflict, contention, contest, crusade, defence, disagreement, dogfight, drive, engagement, enmity, expedition, fight, hostility, hostilities, insurrection, massacre, mission, offensive, operation, rebellion, revolt, riot, rising, scuffle, skirmish, strife, struggle, quarrel, warfare, що є прямими номінаціями концепту.

Концепт WAR реалізується в контексті багатьох концептуальних метафор (фігур мислення, що дозволяють осмислити явища одного виду в термінах явища іншого виду (Lakoff G., 2008; 14). Ми виокремили 42 концептуальні метафори, які реалізують концепт $W A R$ в англомовній лінгвокультурі, та погрупували їх у шість тематичних груп: «Насилля та агресія», «Жива природа», «Нежива природа», «Соціальні явища», «Екзистенціалізм», та «Релігія».

Ключовими концептами в межах першої тематичної групи є концепти насилля, агресії, руйнування, а також суміжні з ним. Всього було виокремлено 7 концептуальних метафор насилля:

WAR is VIOLENCE: «Violence, naked force, has settled more issues in history than has any other factor.» (Robert A. Heinlein);

WAR is A CRIME: «Never think that war, no matter how necessary, nor how justified, is not a crime.» (Ernest Hemingway);

WAR is A KILLER: "An assassin of the future, an executioner of morality.» (S. Glendinning);

WAR is TORTURE: «Every minute of every hour throughout that night was pure torture.» (Alistair Urquhart);

WAR is AN EMOTIONAL TRAUMA: They live in an emotional wasteland. (T. S. Eliot); «I'm ruined beyond repair, is what I fear... And if so, in time we'd both be wretched and bitter.» (Charles Frazier) - війна постає як величезне психо-емоційне навантаження, що травмує психіку індивіда;

WAR is DESTRUCTION: "A scavenger robot wanders in a wasteland created by a war that has destroyed humanity» (C. Robert Cargill). Можна сказати, що ця метафора включає в себе, або принаймні дотична до метафори WAR is SELF-DESTRUCTION: "If we don't end war, war will end us.» (H. G. Wells);

WAR is DAMAGE: «Ruined book it is a melodrama warning society of the irreparable damage war can inflict upon women and men.» (Amy Tintera).

Друга група концептуальних метафор персоніфікую війну, надаючи ій ознак живої істоти (біль, захворювання, смерть). До складу цієї групи входять наступні концептуальні метафори: 
WAR is A LIVING BEING: "The war that brought a fortune to Jo Hertz, transformed him, overnight, from a baggy-kneed old bachelor to a prosperous man» (Ferber Edna);

WAR is A MONSTER: "They were monsters with human faces, in crisp uniforms, marching in lockstep, so banal you don't recognize them for what they are until it's too late.» (Ransom Riggs);

WAR is A DISEASE: "I have no heart for the war, so my heart stops. I As if by a heart attack.» (T. Goff); "At any stage of the process things can go wrong. / The most wrong of these is war.» (P. Wellingham-Jone);

WAR is DEATH: «Death's rancid breath sweeps the land» (Henry Newbolt);

WAR is AN ANIMAL: "Hitler became a European menace largely because the internal weakness of the small Versaillescreated eastern countries made them fall easy prey to German aggression.» (Peter Ferdinand Drucker);

WAR is A PLANT: «And probably none would have been safe, for aggression grows by what it acquires» (Nathaniel Peffer); «The seed of her rebellion is suddently uprooted» (Kanin Garson).

Наступна тематична група включає «фізичні» метафори, або такі, що грунтуються на концептуальній сфері «фізичний світ». Як правило, вони представляють війну в якості якоїсь сили природи, або ж властивостей фізичного світу:

WAR IS A NATURAL PHENOMENON: "They call this war a cloud over the land. But they made the weather and then they stand in the rain and say «Shit, it's raining!» (Charles Frazier);

WAR is A DISASTER: "War is catastrophe. It breaks families in irretrievable pieces.» (Ruta Sepetys) - війна $\epsilon$ потенційно деструктивною через власні сутнісні характеристики та може ототожнюватися з катастрофою;

WAR is DESERT: "As a young soldier stepping off the plane in Saigon, I walked into the quicksand of war for the first time.» (Charles M. Grist); "The world had become a nightmare of choking, smothering, clinging dust particles, a nightmare of sticky heat and stifling dust-filled air.» (Louis L'Amour);

WAR is FIRE: «Everywhere in the System, revolt was flaming» (Simak Clifford D.);

WAR is SOUND: «Twelve-inch, six-inch, and eighteen pounders hammering hell's thunders» (I. Gurne);

WAR is SMELL: The unmentionable odour of death offends the September night. (W. H. Auden);

WAR is A MACHINE: «Heavy artillery bombardment was the main attacking arm which had done what work it could against enemy batteries, machine-gun nests, pill boxes and barbed fire.» (Marcus Clapham);

WAR is A GEOMETRIC SHAPE: The organization works at the front lines of the war on poverty.

Емоційні прояви сприйняття феномену війни як змагання, гри або певного типу соціальної діяльності лягли в основу четвертої групи концептуальних метафор, де більшість одиниць передає нейтральні або позитивні конотації (що загалом є досить нетиповим для реалізації концепту $W A R)$ :

WAR is BUSINESS: «We can export war and have peace here»; "Purveyors of death, destruction and misery allot death on other continents».

WAR is A GAME: "The sickening game of elimination, is played on the field of war.» (Matt Smith); «How come we play war and not peace?» (Bill Watterson);

WAR is A COMPETITION: "But in a contest between a Human and a Green Warrior, I know where I'd put my money»;

WAR is AN ART: "It meant thousands of trained saboteurs, who had learned the arts of destruction in secret war upon the Nazis» (Upton Sinclair);

WAR is A SPORT: "You are fools,» the lieutenant snapped. We observe the rules of war» (Montgomery R. George);

WAR is THEATRE / CINEMA: "Many cities were entered with only a token ballet of warfare» (Christopher Rand); "Let's pretend that all our wars are movies, / epics really, illconceived and over-budget, / let's leave the ending open for a sequel» (E. Evans). 
Четверта група концептуальних метафор («Соціальні явища») доповнює концепт $W A R$ ідеєю змагання та гри. Для англійців важливо знати, що можна і що не можна робити під час війни, іншими словами, ми бачимо тут зв'язок з одним 3 фундаментальних концептів англомовного світу - FAIR PLAY (чесна гра, гра за правилами) - таке розуміння відповідає середньовічному лицарському кодексу поведінки.

П’ята тематична група пов'язана із екзистенціальними концептами абсурдності буття, хаосу, божевілля, смерті, самотності, втрати, світової скорботи, випадковості тощо. Людина сприймається як іграшка в руках фатуму. Виникнення такого світовідчуття пов'язано із впливом французьких екзистенціалістів на англомовну картину світу після Другої світової війни. До цієї тематичної групи належать такі концептуальні метафори:

WAR is CHAOS: "War. That is what they call it to give the illusion of honor and law. It is chaos. Madness and blood and the hunger to win.» (Libba Bray);

WAR is THE WORLD: «This world, «he mused,» is a place of struggle» (Merritt Abraham); «War was always here. Before man was, war waited for him.» (Cormac McCarthy);

WAR is MADNESS: "Throughout the open grassland, to chaotic desert sands, the brave and fair are falling, as the abode of madness stands.» (Matt Smith);

WAR is ABSURDITY: Death becomes absurd and life absurder (W. Owen);

WAR is STUPIDITY: "I do not know with what weapons World War III will be fought, but World War IV will be fought with sticks and stones!» (Albert Einstein);

WAR is MISUNDERSTANDING: "So the whole war is because we can't talk to each other.» (Orson Scott Card); "War is what happens when language fails.» (Margaret Atwood);

WAR is EMPTINESS: "No Man's Land is an eerie sight. $<\ldots>$ In No Man's Land from edge to edge, / And never a living soul walks there / To taste the fresh of the morning air.» (James H. Knight-Adkin);

WAR is POVERTY: "There is never enough to eat, their shoes fall to pieces from marching, their clothes are torn and rotting. If they want new boots or a warmer cloak or maybe a rusted iron half helm, they need to take them from a corpse» (George R. R. Martin);

WAR is SUFFERING: If we had to stand over the mangled corpses of schoolchildren killed in Afghanistan and listen to the wails of their parents, we would not be able to repeat clichés we use to justify war. (Chris Hedges);

WAR is RISK/DANGER: «I think war is a dangerous place.» (George W. Bush) - дана метафора стосується поняття «ймовірність», що може асоціативно варіюватися від стовідсоткового прогнозу до гіпотетичних непередбачуваних ситуацій;

WAR is LOSS / FAILURE: "No one won the last war, and no one will win the next war.» (Eleanor Roosevelt);

WAR is A CHOICE: «War is over ... If you want it.» (John Lennon); "A weapon does not decide whether or not to kill. A weapon is a manifestation of a decision that has already been made.» (Steven Galloway).

Насамкінець, ми ідентифікували 5 концептуальних метафор, що належать до тематичної групи «Релігія»:

WAR is APOCALIPSIS: These, in the day when heaven was falling, The hour when earth's foundations fled, Followed their mercenary calling, And took their wages, and are dead. (A. E. Houseman); «As the shadows grow long from the fall of the sun, it darkens the land of pain.» (Matt Smith);

WAR is DEVIL: «War is the devil. It starts and it consumes and it grows and grows and grows. And otherwise normal men become monsters, too.» (Patrick Ness);

WAR is JUDGMENT DAY: "Under the sod and the dew, / Waiting the judgment day, / Under the one, the Blue, / Under the other, the Gray.» (J. M. Finch);

WAR is HELL: "Mute in the clamour of shells he watched them burst / Spouting dark earth and wire with gusts from hell» (Siegfried Sassoon);

WAR is SIN: "Love for humanity is not a sin. / Preparing for war is»; "War is a battle one cannot win. Win or lose you are committing a sin». 
Варто зазначити, що в рамках художнього дискурсу концепт $W A R$ може реалізуватися одразу через декілька різнопланових концептуальних метафор, наприклад: «Humanity's black hole, / ultimate testimonial to human failure, / great wheel of despair, / end of reason, / abyss of the soul, / mother's lament, / outrageous waste of the possible, / assassin of the future.» (Joseph Aprile).

Насамкінець, за допомогою методу статистичного аналізу ми з'ясували відсоткове співвідношення концептуальних метафор різних тематичних груп. Найпоширенішою групою виявилися екзистенційні метафори, що пов'язано з тим, що війна як соціальне явище змушує людей замислюватися про проблеми існування та своє місце у світі.

\begin{tabular}{|l|l|c|c|}
\hline № & \multicolumn{1}{|c|}{ Тематична група } & Кількість & Відсоток, \% \\
\hline 1 & «Насилля та агресія» & 7 & 17 \\
\hline 2 & «Жива природа» & 6 & 14 \\
\hline 3 & «Нежива природа» & 8 & 18 \\
\hline 4 & «Соціальні явища» & 6 & 14 \\
\hline 5 & «Екзистенціалізм» & 5 & 25 \\
\hline 6 & «Релігія» & & 12 \\
\hline
\end{tabular}

Таблиця 1. Кількісне співвідношення концептуальних метафор, що реалізують концепт WAR

Як засвідчує семантика номінативних одиниць, за допомогою яких вербалізується концепт $W A R$, явище війни розглядається носіями англійської мови здебільшого 3 негативною оцінністю. Зокрема, на нашу думку, найбільш негативним забарвленням відрізняються лексичні одиниці bloodshed (кровопролиття), bloodletting (різанина) та crackdown (придушення протесту).

Висновки і пропозиції. Таким чином, ми розтлумачили поняття концепту $W A R$, проаналізували характер його репрезентації в англомовній лінгвокультурі та виявили ряд прихованих метафоричних моделей, що актуалізуються під час вербальної реалізації концепту WAR. Війна у свідомості англомовних людей виступає як певна сила, що руйнує світовий порядок, та яка призводить до саморуйнування соціуму. Можемо зазначити, що концепт $W A R$ є інтенційно висунутим та акцентованим у англомовній картині світу, а його вербалізації здебільшого мають негативну пейоративну конотацію.

\section{БІБЛІОГРАФІЯ}

1. Брославська Л. Я. Номінативний простір концепту war/війна в американській мовній картині світу / Л. Я. Брославська // Англістика та американістика. - Випуск 13. - 2016. - С. $27-32$.

2. Венедиктова Л. Н. Концепт «война» в языковой картине мира (сопоставительное исследование на материале английского и русского языков): Дис. ... канд. филол. наук / Л.Н. Венедиктова. - Тюмень, 2004. $241 \mathrm{c}$.

3. Верьовкін В. В. Відображення уявлень про війну в античній і сучасній мовній свідомості (на матеріалі давньогрецької, латинської, англійської, німецької та української мов): Дис. ... канд. філол. наук / В.В. Верьовкін. Київ, 2013. -212 с.

4. Вільчинська Т. Концепт - війна: особливості мовної об’єктивації у газетному тексті / Тетяна Вільчинська // Лінгвістичні студії. - Випуск 24. - 2017. - С. $110-114$.

5. Карасик В. И. Языковая кристаллизация смысла: монография / Карасик В. И.; ВГПУ, Науч.-исслед. лаборатория "Аксиологическая лингвистика". - Волгоград: Парадигма, 2010. - 421 с.

6. Кубрякова Е. С. Начальные этапы становления когнитивизма: лингвистика психология - когнитивная наука / Е. С. Кубрякова // Вопросы языкознания, 1994. - С. 34-47.

7. Рабкина Н. Концепт WAR в англоязычной военной поэзии : Дис. ... канд. філол. наук / Н. В. Рябкина. Иркутск, 2009. - 200 с.

8. Стернин И. О понятии лингвокультурной специфики языковых явлений / И. А. Стернин // Язык. Словесность. Культура. - Изд. «АНАЛИТИКА РОДС». - 2011. - С. 8-19. 
9. Шевченко О. Методи дослідження концептів / Шевченко Н.С., Шевченко О.М. // Modern Science: Problems And Innovations: матеріали V Міжнародної науково-практичної конференції. - Стокгольм, Швеція 2020. - C. 385-390.

10. Lakoff G., Johnson M. Metaphors we live by. University of Chicago press. 2008. - 216 p.

\section{REFERENCES}

1. Broslavska L. Ya. (2016.). Nominatyvnyi prostir kontseptu war/viina v amerykanskii movnii kartyni svitu / Broslavskaya L. Ya. [Nominative space of the concept of war in the American language picture of the world] // Anhlistyka ta amerykanistyka. - Vypusk 13. P. 27-32.

2. Venediktova L. N. (2004). Konczept «vojna» v yazy`kovoj kartine mira (sopostavitel’noe issledovanie na materiale anglijskogo i russkogo yazy kov) [The concept of "war" in the linguistic picture of the world (comparative study on the material of the English and Russian languages)]: Dis. ... cand. philol. sciences / L.N. Venediktov. - Tyumen. $241 \mathrm{p}$.

3. Verovkin V. V. (2013). Vidobrazhennia uiavlen pro viinu v antychnii i suchasnii movnii svidomosti (na materiali davnohretskoi, latynskoi, anhliiskoi, nimetskoi ta ukrainskoi mov) [Reflection of ideas about the war in the ancient and modern linguistic consciousness (on the material of ancient Greek, Latin, English, German and Ukrainian languages)]: Dis. ... cand. philol. sciences / B.B. Veryovkin. - Kyiv. 212 p.

4. Vilchynska T. (2017). Kontsept - viina: osoblyvosti movnoi obiektyvatsii u hazetnomu teksti [Concept - war: features of language objectification in a newspaper text] / Tetyana Vilchynska // Linhvistychni studii. - Vypusk 24. P. $110-114$.

5. Karasik V. I. (2010). Yazy`kovaya kristallizacziya smy`sla: monografiya [Linguistic crystallization of meaning]: monograph / Karasik V. I. - Volgograd : Paradigm. 421 p.

6. Kubryakova E. S. (1994). Nachal’ny`e e`tapy` stanovleniya kognitivizma: lingvistika psikhologiya kognitivnaya nauka [Initial stages of the formation of cognitivism: linguistics, psychology - cognitive science] / E.S. Kubryakova // Voprosy`yazy`koznaniya. pp. 34-47.

7. Rabkina N. (2009). Konczept WAR v angloyazy`chnoj voennoj poe'zii [Concept of WAR in English-language military poetry] : Dis. ... cand. philol. sciences / N.V. Ryabkina. - Irkutsk. 200 p.

8. Sternin I. (2011). O ponyatii lingvokul 'turnoj speczifiki yazy'kovy'kh yavlenij [ On the concept of linguocultural specificity of linguistic phenomena] / I. A. Sternin // Yazy'k. Slovesnost'. Kul'tura. - Izd. «ANALITIKA RODS». S. 819.

9. Shevchenko O. (2020). Metody doslidzhennia kontseptiv [Methods of research of concepts] / Shevchenko N.S., Shevchenko O.M. // Modern Science: Problems And Innovations: materialy V Mizhnarodnoi naukovo-praktychnoi konferentsii. - Stockholm, Sweden.P. 385-390.

10. Lakoff G., Johnson M. (2008). Metaphors we live by. University of Chicago press. 216 p.

\section{ВІДОМОСТІ ПРО АВТОРА}

Олена Шевченко - кандидат педагогічних наук, доцент кафедри українознавства та гуманітарної підготовки Української медичної стоматологічної академії.

Наукові інтереси: мова художнього твору, когнітивна лінгвістика, методика викладання іноземної мови.

INFORMATION ABOUT THE AUTHOR

Olena Shevchenko - Candidate of Philology, Associate Professor of the Department of Ukrainian Studies and Humanitarian Training if the Ukrainian Medical Dental Academy.

Scientific interests: language of artwork, cognitive linguistics, methods of teaching a foreign language. 